\title{
Pelatihan Produk Keripik Tempe Sagu Hezel Di Desa Pandau Jaya Kecamatan Siak Hulu Kabupaten Kampar
}

\author{
DWIKA LODIA PUTRI ${ }^{1}$; SYAFRUL RAJAB ${ }^{2}$; AZNURIYANDI $^{3}$ \\ Universitas Lancang Kuning \\ Jln. Yos Sudarso KM 08 Rumbai Telp. (0761) 52581 \\ E-mail : lodiaputri_62@yahoo.com
}

\begin{abstract}
Community service activity aims to provide product training to make sagu hezel tempe chips ready for sale and able to grow entrepreneurial spirit and to know the responses of housewives to training the product of tempe chips sagu hezel which also increase family income and foster entrepreneurial spirit. This method of community service activity using lecture method, direct demonstration practiced by participants, and question and answer. Lecture method is used to convey general knowledge about the product of tempe chips of sagu hezel, which include soybean, sagu and other spices. Demonstrarions are used to provide direct skill on the process of making tempe sagu hezel product. Questions are used to complement the things that have not been accommodated by the above method. The training involves lecturers majoring in accounting in collaboration with housewives in the village of Pandau jaya subdistrict Siak Hulu Kampar District as the target subjects.
\end{abstract}

Keywords: Tempe Product, Tempe Chips, Entrepreneurship Training, Housewives

Desa Pandau Jaya Kecamatan Siak Hulu Kabupaten Kampar merupakan kecamatan yang terletak paling dekat dengan ibukota Provinsi Riau. Jarak ibukota kecamatan dengan ibukota Kabupaten sekitar $75 \mathrm{~km}$, sedangkan jarak dengan ibukota Provinsi sekitar $28 \mathrm{~km}$ dan jarak ibukota kecamatan dengan desa/kelurahan yang terjauh sekitar $48 \mathrm{~km}$. Keadaan topografi tanah sebagian besar $87 \%$ merupakan tanah datar dan $13 \%$ bergelombang dan berbukit. Iklim yang terdapat di Kecamatan Siak Hulu adalah iklim tropis yang dipengaruhi angin laut, dengan ketinggian tanah dari permukaan laut sekitar $93 \mathrm{~m}$.

Kegiatan pengabdian ini ditujukan kepada ibu-ibu rumah tangga di desa Pandau Jaya Kecamatan Siak Hulu Kabupaten Kampar dalam mengisi waktu luangnya dengan diadakan pelatihan produk keeripik tempe sagu hezel, sehingga dapat menghasilkan tambahan uang sehingga menumbuhkan jiwa kewirausahaan. Menurut Suryana (2006), memiliki kemampuan dalam menggunakan dan mengkombinasikan sumber daya seperti keuangan, material, tenaga kerja, keterampilan untuk menghasilkan produk, proses produksi, bisnis, organisasi usaha baru penting untuk dapat secara bersamasama membentuk suatu usaha bersama dalam rangka meningkatkan taraf kehidupan keluarga.

Keripik Tempe termasuk salah satu makanan yang banyak disukai oleh masyarakat dan dalam proses pembuatannya tidak terlalu sulit. Besarnya minat masyarakat akan produk keripik tempe merupakan salah satu peluang bisnis yang menjanjikan.

Walaupun potensi bisnis produk tempe sangat menjanjikan, bukan berarti industri ini tidak menghadapi kendala. Ada banyak faktor yang menjadi hambatan-hambatan UKM keripik tempe untuk mengembangkan bisnis seperti misalnya: (1) banyak UKM yang masih mendistribusikan produk tempenya hanya di daerah sekitar saja seperti warungwarung sekitar atau mengirimnya ke pengumpul karena terbatasnya ilmu dan informasi yang dimilikinya (2) Kurangnya pengetahuan UKM akan strategi pemasaran praktis dimana produk yang dibuat oleh UKM hanya berupa produk curah tanpa merek atau label yang 
memberikan identitas unik pada produk, (3) Minimnya financial literacy dari para pelaku usaha dimana hampir semua bisnis tidak memiliki laporan keuangan yang baku sehingga menyulitkan mereka untuk mengetahui modal kerja, pengeluaran dan laba yang diterima secara pasti dari operasi, (4) rendahnya inovasi, pengembangan nilai tambah dan diferensiasi bisnis sehingga membuat produk-produk mereka hanyalah menjadi bisnis komoditas yang bersaing dengan harga yang rendah.

\section{METODE}

Metode yang akan dilakukan oleh tim selama kegiatan pengabdian bagi masyarakat dengan Mitra Kelompok Usaha di Desa Pandau Jaya Kecamatan Siak Hulu Kabupaten Kampar.

a. Metode Ceramah

Dengan cara melakukan motivasi dengan menjelaskan langsung kepada mitra dengan tujuan untuk membangkitkan gairah jiwa bisnis/kewirausahaan.

b. Metode Praktek

Dengan cara melakukan praktek secara langsung sesuai dengan materi yang akan disampaikan kepada mitra. Melalui kegiatan praktek langsung diharapkan mitra mendapatkan pengetahuan tentang cara mengolah produk keripik tempe sagu hezel, sehingga menambah kegunaan dari produk tersebut.

\section{c. Enterpreneurship Motivation}

Pada kegiatan ini akan dilakukan pemberian motivasi pentingnya kewirausahaan. Kegiatan ini dilakukan dalam bentuk pelatihan motivasi jiwa wirausaha dalam bentuk tukar pengalaman dengan usahawan lainnya yang berasal dari ibu rumah tangga yang sukses untuk meningkatkan gairah jiwa wirausaha mitra. Kegiatan ini diarahkan untuk membangun mindset jiwa wirausaha bagi mitra usaha sehingga dapat menimbulkan motivasi jiwa wirausaha dan pengembangan usaha mitra. Kegiatan ini dilakukan dalam bentuk diskusi interaktif untuk mengungkap permasalahan dan potensi usaha yang dapat dikembangkan oleh mitra maupun kelompok usaha ibu rumah tangga yang lainnya.

\section{HASIL}

Pelaksanaan kegiatan pengabdian kepada masyarakat ini dilakukan di Desa Pandau Jaya Kecamatan Siak Hulu Kabupaten Kampar dengan mitranya kelompok ibu rumah tangga sebagai kader PKK di Desa Pandau Jaya. Para peserta yang hadir pada waktu pelaksanaan kegiatan berjumlah 37 orang dengan tingkat pendidikan SMP dan SMA dengan usia 25 -40 tahun.

Tim pelaksana terdiri dari 3 orang dengan peran masing-masing, Ketua Tim (Dwika Lodia Putri. SE.,M.Ak) memberikan materi tentang kewirausahaan, praktek pelatihan produk keripik tempe sagu hezel; sedangkan anggota Tim (Syafrul Rajab, SE.,MM) memberikan materi pengembangan usaha dan Aznuriyandi.,SE.,M.Si, memberikan materi pemasaran.

Pada Dasarnya para peserta antusias dalam menerima materi yang diberikan oleh Tim Pengabdian Masyarakat, kita juga maklum dengan keterbatasan kemampuan nalar yang belum terarah untuk memulai usaha sampingan yang akan mendatangkan keuntungan atau meningkatkan pendapatan keluarga. Maka dalam memberikan pelatihan produk keripik tempe sagu hezel yang dapat memenuhi pangsa pasar. Produk Hasil Olahan kelompok Ibu Rumah Tangga pada Desa Pandau Jaya Kecamatan Siak Hulu Kabupaten Kampar, materi dan bahan pembekalan kita harus mengulang mengulang sampai mereka dapat memahaminya dengan bahasa yang sangat sederhana.

Dari hasil ceramah, diskusi, tanya jawab, kami tim dapat menyimpulkan bahwa peserta sebagian besar sudah memahami tentang bagaimana meningkatkan pendapatan keluarga serta meraih pangsa pasar, hal ini dapat dilihat dari hasil quisioner setelah mendapatkan pembekalan dan materi tentang bagaimana meningkatkan pendapatan keluarga untuk 
meraih pangsa pasar. Tim dapat meyakinkan bahwa meskipun mereka sebagai ibu-ibu rumah tangga, dengan adanya waktu luang dan kemampuan untuk maju dan bisa membantu ekonomi keluarga, dari ibu-ibu PKK di Desa Pandau Jaya Kecamatan Siak Hulu Kabupaten Kampar dapat berkreasi dari pengabdian yang telah dilakukan.

Dalam kegiatan pengabdian masyarakat ini dengan cara menyebarkan quisioner sebelum dan sesudah pelaksanaan pengabdian. Adapun untuk mengetahui pengetahuan dan pemahaman tentang pelatihan produk keripik tempe sagu hezel, dapat dilihat dari tabel 1 di bawah ini:

Tebel 1. Hasil Kuesioner Pengabdian Kepada Masyarakat

\begin{tabular}{|c|c|c|c|c|}
\hline \multirow[t]{2}{*}{$\mathrm{Nc}$} & \multirow{2}{*}{$\begin{array}{l}\text { Komponen } \\
\text { Kuesioner }\end{array}$} & \multicolumn{3}{|c|}{ Alternatif Jawaban } \\
\hline & & $\mathrm{T}$ & $\mathrm{N}$ & $\mathrm{Y}$ \\
\hline 1. & $\begin{array}{l}\text { Pengetahuan } \\
\text { mengenai } \\
\text { kewirausahaan } \\
\text { dan peluang } \\
\text { usaha }\end{array}$ & $40 \%$ & - & $60 \%$ \\
\hline 2. & $\begin{array}{l}\text { Pengetahuan cara } \\
\text { pembuatan } \\
\text { produk keripik } \\
\text { tempe sagu hezel }\end{array}$ & $90 \%$ & - & $10 \%$ \\
\hline 3. & Praktek & - & - & $100 \%$ \\
\hline 4. & $\begin{array}{l}\text { Pengetahuan nara } \\
\text { sumber/pelaksana } \\
\text { kegiatan }\end{array}$ & - & - & $100 \%$ \\
\hline 5 . & $\begin{array}{l}\text { Minat peserta } \\
\text { untuk } \\
\text { mengembangkan } \\
\text { pembuatan } \\
\text { produk keripik } \\
\text { tempe sagu hezel }\end{array}$ & $10 \%$ & $15 \%$ & $75 \%$ \\
\hline
\end{tabular}

Keterangan: $\mathrm{T}=$ Tidak. $\mathrm{N}=$ Netral .

$\mathrm{Y}=\mathrm{Ya}$

Sumber: Data Olahan 2018

Dari rekapitulasi kuesioner diatas maka dapat diketahui bahwa terjadi peningkatan pengetahuan peserta kegiatan mengenai kewirausahaan dan peluang usaha mandiri meningkat dimana peserta yang pada awalnya hanya $60 \%$ saja yang mengetahui menjadi $100 \%$ mengetahui dan memahami mengenai kewirausahaan. Sedangkan pengetahuan mengenai cara pembuatan produk keripik tempe sagu hezel meningkat menjadi $100 \%$, dari awalnya hanya $10 \%$ saja yang mengetahuinya. Sedangkan $100 \%$ peserta mengetahui dan memahami proses pembuatan produk keripik sagu hezel melalui praktek langsung yang didampingi oleh tim pelaksana kegiatan pengabdian. Dan $75 \%$ peserta kegiatan pengabdian berminat untuk menjadikan produk keripik tempe sagu hezel ini sebagai peluang usaha mandiri.

\section{PEMBAHASAN}

Dari pantauan kami, memang Pelatihan dan tanya jawab yang kami berikan berpengaruh terhadap penerimaan materi yang kami berikan, untuk kelompok ibu-ibu rumah tangga kegiatan Kewirausahaan dan Pemasaran Produk Tempe sagu hezel. Hasil olahan produk sagu hezel pada ibu-ibu rumah tangga di Desa Pandau Jaya Kecamatan Siak Hulu Kabupaten Kampar, cepat memahami apa yang disampaikan oleh Tim Kami.

Pada dasarnya para peserta antusias dalam menerima mater-materi yang diberikan oleh Tim Pengabdian Masyarakat, kita juga maklum dengan keterbatasan kemampuan nalar yang belum terarah untuk memulai usaha sampingan yang akan mendatangkan keuntungan atau meningkatkan pendapatan keluarga. Maka dalam memberikan pelatihan produk sagu hezel yang dapat memenuhi pangsa pasar dan meningkatkan pendapatan keluarga. Produk hasil olahan kelompok ibu-ibu rumah tangga pada Desa Pandau Jaya Kecamatan Siak Hulu Kabupaten Kampar, materi dan bahan pembekalan kita harus mengulang-ulang sampai mereka dapat memahaminya dengan bahasa yang sangat sederhana.

Hasil penelitian ini sejalan dengan apa yang disampaikan oleh Rahman (2017) bahwa melalui pengembangan modal manusia dalam membangun kreatifitas dan juga memberdayakan sumber daya yang ada akan memberikan nilai tambah dalam menghasilkan produk yang bersaing. 


\section{SIMPULAN}

Metode pelaksanaan yang dilakukan pada program pengabdian ini adalah pelatihan manajemen usaha, pelatihan produksi, pelatihan cara pembuatan produk keripik tempe sagu hezel, pelatihan administrasi serta pendampingan.

Kegiatan pengabdian masyarakat ini dengan cara pemberian pembekalan tentang meningkatkan pendapatan keluarga dan pemasaran produk keripik tempe sagu hezel untuk meraih pangsa pasar.

Para peserta sebelum diadakan pembekalan tentang kewirausahaan dan Pemasaran Produk keripik tempe sagu hezel, banyak yang belum memahami arti pentingnya keahlian yang dimiliki untuk dapat membuka peluang agar dapat meraih pangsa pasar. Dan setelah dilakukan pembekalan tentang kewirausahaan dan pemasaran Produk keripik tempe sagu hezel, mereka mulai memahami meskipun sulit untuk dapat menerapkannya, karena pemikiran para ibu-ibu dari kelompok mitra tersebut bahwa berwirausaha dan memasarkan Produk membutuhkan modal yang besar. Sedangkan menurut mereka hanya kemampuan keahlian yang mereka miliki saja.

Kami sebagai Tim menyarankan kepada para peserta agar mereka lebih menggali keahlian yang dia miliki, termasuk memanfaatkan peluang usaha yang ada, terutama berkenaan dengan keahlian yang dia miliki dibidang pembuatan hasil industri rumahan (pembuatan produk keripik tempe sagu hezel). Begitu juga dengan keahlian yang ada, mereka dapat mengembangkan hasil olahan dengan mengikuti kesukaan atau kegemaran dari para masyarakat.

\section{DAFTAR RUJUKAN}

Bambang, Supriyatno. 2014. Daya Inovasi dan Kreativitas Produk Dalam Pengembangan Usaha Keripik Tempe di Kabupaten Ngawi. Jurnal Ilmiah STKIP PGRI Ngawi. Vol.13 No.1. p65-p71.

M. Ariza., Asry W. 2015. Pengembangan UKM Keripik Tempe di Pekon Way Jaha Kecamatan Pugung Kabupaten Tanggamus. Jurnal Teknologi Informasi dan Bisnis Pengabdian Masyarakat Darmajaya. Vol.01, N0.2, Agustus 2015.

Rahman, F. (2017). Peran Modal Manusia Dan Modal Investasi Terhadap Nilai Produksi Industri Kecil Di Kota Pekanbaru. Jurnal Benefita, 2(1), 1-9.

Suryana, 2006. Kewirausaan Pedoman Praktis: Kiat, dan Proses Menuju Sukses . Jakarta. Penerbit Salemba. 